\title{
The beginnings of Polish lexicography: How to present glosses in the medieval dictionary in the digital age ${ }^{\dagger}$
}

\author{
Katarzyna Jasińska ${ }^{\circledR \oplus \star}$ \\ Institute of Polish Language, Polish Academy of Sciences, Al. Mickiewicza 31, 31-120 Kraków, Poland
}

\section{Article info}

History:

Received September 17, 2021

Accepted October 5, 2021

Published December 12, 2021

Key words:

diachrony

glosses

text editing

\begin{abstract}
The purpose of this paper is to show how this specific type of attestationsPolish glosses in Latin dictionaries - can be presented in the electronic form. The starting point for my considerations will be the online database Rozariusze $z$ polskimiglosami (Rosarii with Polish glosses - rozariusze.ijp.pan.pl). The database collects Polish vocabulary written in the so-called rosarii, i.e. texts representing the Polish redaction of the Vocabularius Ex quo dictionary. The online tool allows users to view and search the collected resources in the following layouts: attestations, entries, concordance. The database was created to collect the elaboration of Polish glosses in the so-called rosarii, but it also may be an inspiration or a partial model for research of such attestations in the other vernacular languages.
\end{abstract}

\section{Introduction}

Among the great medieval Latin lexicographic works that were brought into the Polish lands during the $14^{\text {th }}$ and $15^{\text {th }}$ century was a dictionary called Vocabularius Ex quo of German origin. It was a compilation of other texts of encyclopedic nature such as the Elementarium doctrine erudimentum (mid-1 $1^{\text {th }}$ century) written by Papias, the Magne derivationes (late $12^{\text {th }}$ century) by Huguccio of Pisa, the Catholicon by John of Genoa (1286) and the Brevilogus (late $14^{\text {th }}$ century) ${ }^{1}$. The Vocabularius Ex quo $\left(14^{\text {th }} / 15^{\text {th }}\right.$ century) included semantic and grammatical information and, beyond this, German equivalents of Latin lemmas (Grübmuller, 1990, p. 2040-2041).

In Poland the dictionary was adapted to the needs of local recipients. Since it has been modified here, we can actually speak about a Polish redaction of Vocabularius Ex quo. There are several differences between the typical version of Vocabularius Ex quo and the Polish one ${ }^{2}$ : an extended incipit, an elaborate ending, changed layout and the modified system of grammatical symbols used in the original version, omitted German translation of the Latin words and the addition of Polish glosses, extended definitions with additional semantic information and added or omitted entries (Jasińska et al., 2019, p. 148-160).

Dictionaries that belong to the Polish redaction ${ }^{3}$ of Vocabularius Ex quo are known as rosarii (sg. rosarius). The name comes from the fragment of the incipit where features of the work are presented: "Rosarius propter sui decorum" ('a rosarius for its beauty'). Polish glosses that appear in such dictionaries

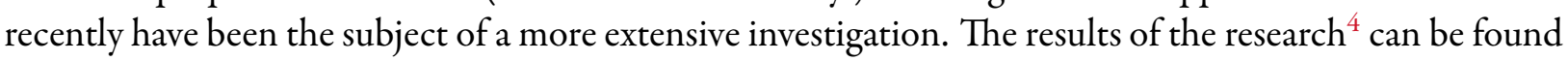
in the database Rozariusze z polskimi glosami (Rosarii with Polish glosses); abbreviation: RPG.

\footnotetext{
†The project entitled "Polish Vocabulary in $15^{\text {th }}$-Century Latin Dictionaries Called Rosarii: A Comparative Study", project leader prof. Ewa Deptuchowa, financed by the National Science Centre (decision number: 2016/21/B/HS2/01249), was conducted at the Institute of Polish Language of the Polish Academy of Sciences between 2017 and 2021.

^Email address: katarzyna.jasinska@ijp.pan.pl.

${ }^{1}$ For description of individual medieval dictionaries see Grübmuller (1967), Considine (2019), Deptuchowa et al. (2020).

${ }^{2}$ For detailed information see Jasińska et al. (2019).

${ }^{3}$ In the critical edition of Vocabularius Ex quo, Grübmuller (1988-2001, p. 113-116) distinguished five main manuscripts and one printed redaction of this dictionary. Polish redaction may belong to the group of manuscripts called "free redaction".

${ }^{4}$ The studies involved: paleographic, semantic, grammatical and translational aspects of Polish glosses. The database
} 


\section{The database $\mathbf{R P G}^{5}$}

The presented database contains Polish material from all of the text sources described in the literature as rosarii. During the analysis it was observed that they actually belong to several types of dictionaries (Deptuchowa et al., 2020, p. 21-31). The final version of the text sources arrangement is as follows: 5 copies of rosarii: RozKap (1450), RozOss I (XV p. post.), RozOss II (1476, XV p. post), RozOss III (XV p. post), RozPaul (1440), 3 copies of Brevilogus (or its Polish redaction): WokJag (1448), WokPet I (XV p. post), WokRacz (1442), 8 copies of an unknown type of dictionaries (probably rosarii): WokPet II (XV p. post), WokPet III (XV I), WokPet IV (XV p. post), WokPet V (1462), WokPet VI (1473), WokPet VII (1463, XV ex.), WokPet VIII (1457), WokPet IX (1460), 1 copy of the Vocabularius Ex quo incunabulum: WokLub (ed. 1490, glosses ca 1500).

The online tool allows users to view and search the collected resources in 3 layouts: entries, attestations and concordance (described below). In addition, the information about the text sources is given in a separate section.

\subsection{Attestations}

The basic entity in this layout is the Polish gloss presented in transliteration. The attestations are listed alphabetically. After every gloss there is a text signature which is actually an active link to the individual attestation which contains that individual gloss.

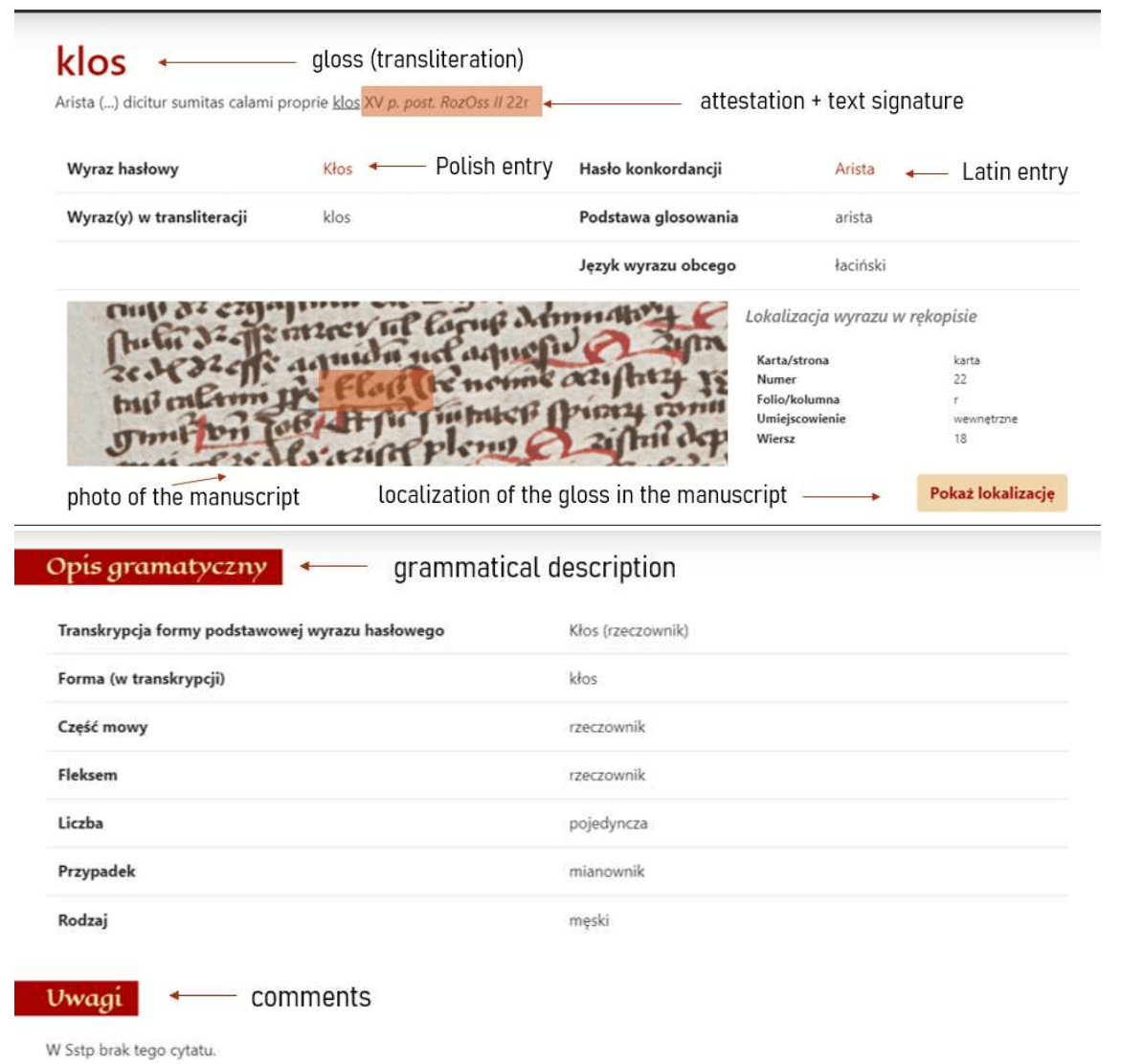

Figure 1: Attestation klos in the database RPG

RPG collects elaboration of the individual attestation. For a comprehensive description of the results of the research see also Deptuchowa et al. (2020), where linguistic material is presented in another way. The individual manuscript is the starting point. Beyond its description, the summary studies on Latin basis and Polish glosses recorded in investigated dictionary is provided.

${ }^{5}$ See rozariusze.ijp.pan.pl. 
The exemplary attestation is presented in Fig. 1. As a headword of the attestation the gloss in transliteration is used $\left(k_{l o s}\right)^{6}$. Below the gloss is repeated, but it is placed in the full Latin context (Arista... dicitur sumitas calami proprie klos). The Polish word is underlined. Next the text signature is given. It consists of: date (XVp. post.), short name of the text source (RozOss II) and folium of the manuscript $\left(22^{\mathrm{r}}\right)$.

Then the section with the basic information is presented. Glosses are collected in the form of a Polish dictionary and in the form of a Latin concordance, so in this section there is an assignment of the gloss to the Polish (Ktos) and Latin entry (Arista). Thanks to such a solution-which has various superior values - the users can see how many times and in what textual form an individual lexeme is attested in the investigated dictionaries. On the other hand, it can be observed how the Latin word is translated into Polish.

There is a photograph of the fragment of manuscript that contains the attestation below the information section. After clicking the yellow button "Pokaż lokalizację" the localization of attestation in the manuscript is presented (folium $22^{\mathrm{r}}$, type of gloss: internal, row no. 18).

Beyond this there is a grammatical section where the information about the part of speech and its grammatical values (noun, singular number, nominative case, masculine gender) is given. The last section includes comments.

\subsection{Entries}

The basic entity in this layout is the Polish entry presented in transcription. Entries are listed alphabetically. After every gloss the part of speech is given. It is useful in the case of homonyms. On that list there are also reference entities. They are most often phonetic variants of the main entries.

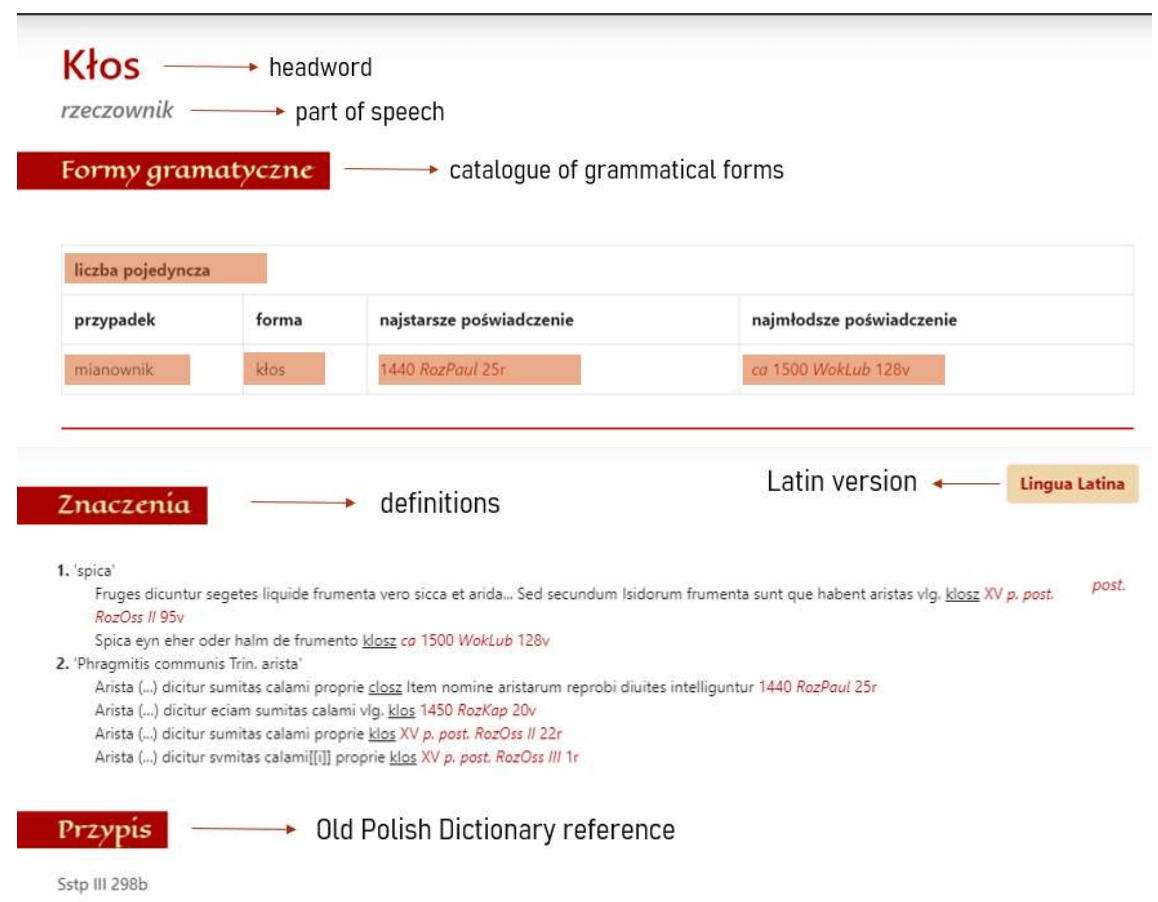

Figure 2: Polish entry Ktos in the database RPG

The exemplary entry is presented in Fig. 2. The transcribed Old Polish form of the word is given as a headword of the entry (Ktos). Below the part of speech and catalogue of the grammatical forms are given. The catalogue consists of grammatical description (singular number, nominative case), then transcribed form of the word $(k t o s)$ and signature of the oldest $\left(1440\right.$ RozPaul $\left.25^{\mathrm{r}}\right)$ and youngest text $(c a 1500$ WokLub $128^{\mathrm{v}}$ ) attestation of the entry.

\footnotetext{
6'ear of grain'.
} 
Next, the semantic section is presented. In that part of the entry all of its attestations can be seen. Every attestation that makes up the entry is assigned to a particular definition (1. inflorescence of some grasses and cereals', 2. 'inflorescence of Phragmitis communis Trin.'). The text signature is an active link, so the users can easily switch to that individual attestation. After clicking the yellow button "Lingua Latina" the Latin version of the definition is presented.

Below the semantic section there is also a reference to the Old Polish Dictionary (Urbańczyk, 19532002), which is the largest dictionary of the earliest stage of the Polish language development (Sstp III 298b).

\subsection{Concordance}

The basic entity in this layout is the Latin entry. Entries are listed alphabetically. After the Latin headword the Polish equivalents of that word are given.

The idea of the Latin concordance is to present attestations that appear in the individual Latin entries. It is possible because text sources are dictionaries. The concordance is in fact a kind of an abstract, ideal Latin dictionary that collects all of Polish glosses inside.

The exemplary entry is presented in Fig. 3. As a headword of the concordance entry the Latin word in its medieval form is given (Arista). Next, the list of all the text sources according to their chronology is presented. The list includes short names of the text sources (RozPaul, WokRacz, WokJag, RozKap, WokPet VIII, WokPet IX, WokPet V, WokPet VII, WokPet VI, RozOss II, RozOss III, RozOss I, WokPet I, WokPet II, WokPet III, WokPet IV, WokLub). If the Polish gloss appears in such a Latin entry of the text source, it is visible next to the short name of the text source (RozPaul, RozKap, RozOss II, RozOss III). The highlighted Polish gloss is an active link, so users can easily switch to the individual attestation.

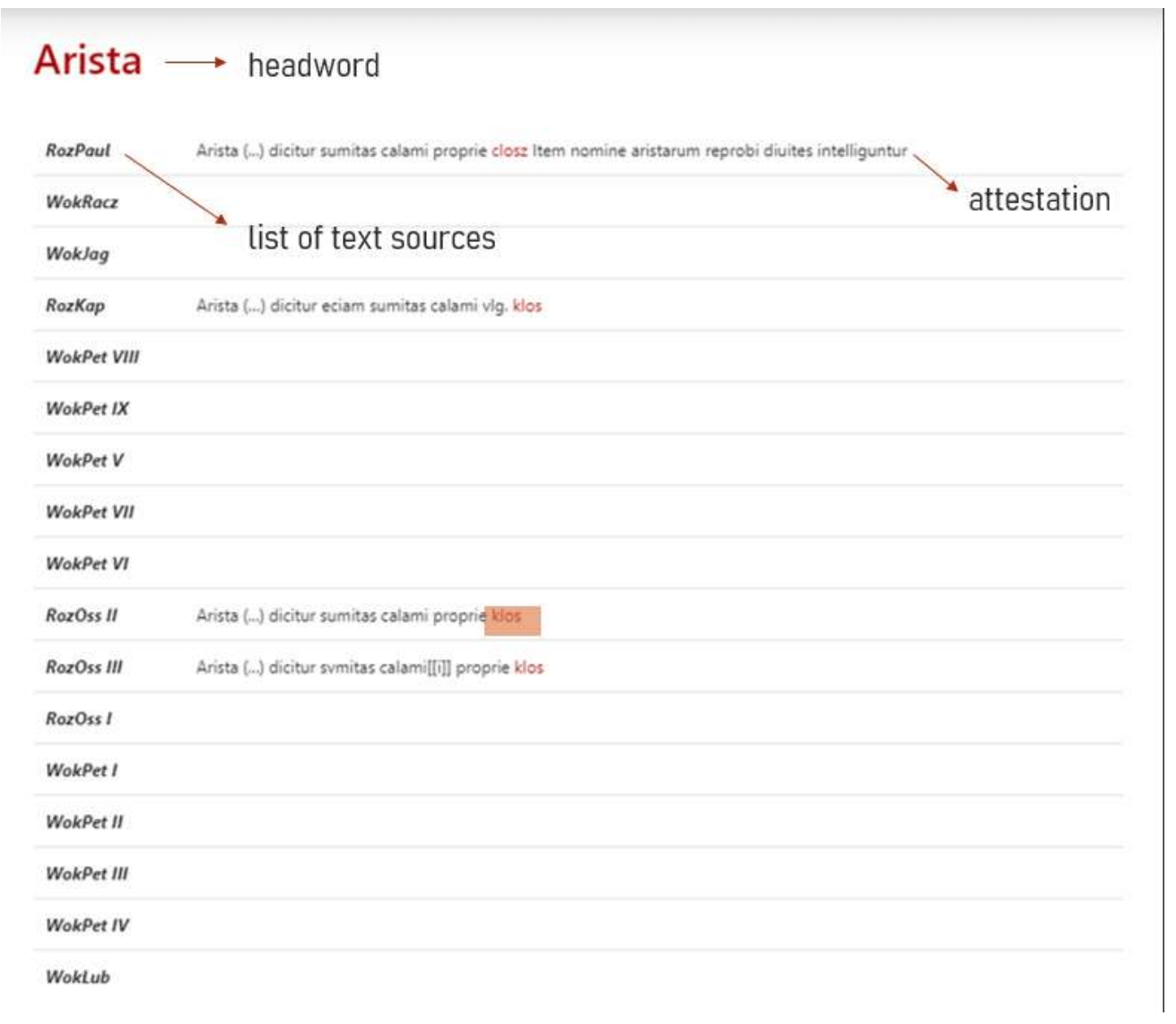

Figure 3: The Latin entry Arista in the database RPG 


\subsection{The database in numbers}

Text material presented in the database includes in all: 6402 attestations, 4197 Polish entries, 3708 Latin entries and 17 text sources.

One and the same gloss is presented in the database in three different ways. First there is a precise description of the attestation, so the Polish gloss in Latin context. The second one is the gloss as part of the Polish dictionary which includes all of the words that appear in the text sources. The third one is the gloss as a part of an abstract dictionary: the Latin concordance.

\section{Conclusions}

The database RPG is the first attempt to present research about Polish medieval dictionaries in a modern way. The possible paths of the enlargement of the database are: adding new text sources (rosarii), comparison with the other types of dictionaries with Polish glosses (Brevilogus, mammotrectus) and comparison with the parallel text sources with glosses in vernacular languages. The presented online tool also has some weaknesses. There is no English version of the database and no access to the tool for external users for the time being.

However, the indirect goal of the database was to interest other investigators not only with the text material itself, but also with the method of presenting vernacular glosses in Latin dictionaries. Perhaps it will be possible to improve this online tool to make it more accessible for other scholars in the near future.

\section{Bibliography}

Considine, J. (2019). Medieval Latin Christendom, in Considine, J. (ed.), The Cambridge World History of Lexicography, Cambridge University Press, Cambridge, p. 267-289, Crossref.

Deptuchowa, E. et al. (eds) (2020). Rozariusze z polskimi glosami, Prace Instytutu Języka Polskiego PAN, Kraków.

Grübmuller, K. (1967). Vocabularius Ex quo. Untersuchungen zu lateinisch-deutschen Vokabularen des Spätmittelalters, C. H. Beck'sche Verlagsbuchhandlung, München.

Grübmuller, K. (ed.) (1988-2001). Vocabularius Ex quo. Überlieferungsgeschichtliche Ausgabe, vols. I-VI, Max Niemeyer Verlag, Tübingen.

Grübmuller, K. (1990). Die deutsche Lexikographie von den Anfängen bis zum Beginn des 17. Jahrunderts, in Hausmann, F.J. et al. (eds), Wörterbücher/Dictionaries/Dictionnaires (An International Encyclopedia of Lexicography), vol. II, Walter de Gruyter, Berlin, p. 2037-2049.

Jasińska, K. et al. (2019). Which Dictionary is Beautiful, Affluent and Concise at the Same Time? (in 15 th -century Poland), in Benati, Ch. \& Händl, C. (eds), From Glosses to Dictionaries: The Beginnings of Lexicography, Cambridge Scholars Publishing, Newcastle upon Tyne, p. 147-163.

RPG = Deptuchowa, E. et al. (eds) (2021). Rozariusze z polskimi glosami. Internetowa baza danych, IT Godny M., Kraków, online].

Urbańczyk, S. (ed.) (1953-2002). Stownik staropolski, vols. I-XI, Instytut Języka Polskiego Polskiej Akademii Nauk, Kraków. 